\title{
ТВОРЧЕСКИЙ ПРОЕКТ ПАБЛИК-АРТ «АРТ-МУНХА-2018. МОЙ СЕВЕР» ИМ. А. П. МУНХАЛОВА
}

\section{CREATIVE PROJECT PUBLIC ART "ART-MUNHA-2018. MY NORTH» NAMED AFTER A.P. MUNKHALOV}

\section{O. Pinigina \\ T. Shaposhnikova \\ N. Komissarova}

Summary: The article is devoted to the implementation of social and cultural projects, the formation of artistic culture and attraction to the General artistic and creative space, the development and popularization of new trends in contemporary art, attracting the attention of children, youth and adults to a comprehensive stud.

Keywords: national-cultural policy, personality-oriented approach, interregional project, art education, public art, Art-Muncha.

\section{Пинигина Ольга Николаевна \\ к.п.н., дочент, ФГБОУ ВО «Арктический государственный институт культуры и искусств» \\ cddo@agiki.ru \\ Шапошникова Туйаара Ефимовна}

Доцент, ФГБОУ ВО «Арктический государственный институт культуры и искусств» te.shaposhnikova@agiki.ru Комиссарова Надежда Сергеевна

Дочент, ФГБОУ ВО «Арктический государственный институт культуры и искусств»

fizi_09@mail.ru

Аннотация: Статья посвящена реализации социально-культурных проектов, формированию художественной культуры и привлечению к всеобщему художественно-творческому пространству, освоению и популяризации новых направлений современного искусства, привлечению внимания детей, молодежи и взрослых к комплексному изучению и сохранению культурного наследия своей малой родины.

Ключевые слова: национально-культурная политика, личностно-ориентированный подход, межрегиональный проект, художественное воспитание, паблик-арт, Арт-Мунха.

ного творчества; привлечение творчески одаренных детей живущих в республике Саха (Якутия) с участием других регионов РФ к участию в конкурсной программе Межрегионального конкурса современного искусства: паблик-арт «Арт-Мунха-2018. Мой Север» им. А.П. Мунхалова», организация и проведение мастер-классов.

Новизна статьи заключается в том, что одним из важнейших компонентов, способствующих созданию и поддержке на высоком уровне культурного потенциала республики, является налаженная система поиска и обучения талантливых детей и молодежи регионов Севера. Реализация проекта была направлена на выявление и развитие талантливой, творчески одаренной молодежи, способной находить эффективные решения и проявлять инициативу. Современное искусство является одним из инструментов решающих основную задачу по вовлечению детей в игровой форме в новую реальность.

Арктический государственный институт культуры и искусств поддерживает проекты, связанные с привлечением внимания детей и молодежи к сохранению и дальнейшему развитию многовековой традиционной культуры народов Севера, Сибири, Дальнего Востока, Арктического региона нашей страны. Именно в их руках формируется современная многонациональная культу- 
ра России. В век цифровых технологий, когда компьютеры выдают готовые решения, глобальная сеть диктует нам образ мыслей, способность думать творчески становится ценнее вдвойне. Будущее - за теми, кто умеет творить. Идея, творчество становится главным ресурсом не только отдельно взятого человека или семьи, и в целом региона, страны. И мы как вуз, понимая всю ответственность, возложенную на нас государством, стараемся не ограничиваться только лишь профессиональной подготовкой, а мыслить и действовать шире, и посредством различных проектов выходить на межрегиональный уровень, охватывать детей, начиная со школьной скамьи, и самое главное - давать возможность заявить талантам из всех районов, поселков. Сегодня это участие в конкурсе, завтра мы увидим, что это был первый шаг к большому яркому пути [3].

Студенты кафедры живописи и графики Арктического государственного института культуры и искусств представляют собой креативную, с большим потенциалом творческую силу, которую можно направить на реализацию социально-культурных проектов, где будущие специалисты могут опробовать свои профессиональные компетенции в реальных условиях.

В 2018 году кафедра участвовала с проектом «Межрегиональный конкурс детского рисунка в форме пабликарт «Арт-Мунха-2018.Мой Север» им. А.П. Мунхалова в конкурсе на получение грантов Некоммерческой организации «Целевой фонд будущих поколений Республики Саха (Якутия)». Отработав проектную часть и пройдя экспертизу, проект получил грант Фонда в рамках подпрограммы «Развитие» на выявление и развитие талантливых и одаренных детей в сфере культуры и искусства» (700 000 руб.).

Реализация проекта «Арт-Мунха. Мой Север-2018» была направлена на выявление и развитие талантливой, творчески одаренной молодежи, способной находить эффективные решения и проявлять инициативу. Современное искусство является одним из инструментов решающих основную задачу по вовлечению детей в игровой форме в новую реальность. Одним из важнейших компонентов, способствующих созданию и поддержке на высоком уровне культурного потенциала республики, является налаженная система поиска и обучения талантливых детей и молодежи регионов Севера.

Название проекта - «Арт-мунха» - имеет несколько объяснений: паблик-арт собирает творческих людей как бы «в сеть», что символизирует рыбалку, также название созвучно с фамилией наставника многих творцов - народного художника Афанасия Мунхалова [1].

Мунхалов Афанасий Петрович (1935-2014)-график, народный художник РСФСР (1982),член-корреспондент
Российской Академии художеств (2012), действительный член Академии Духовности Республики Саха (Якутия) (1995),профессор, первый лауреат Государственной премии ЯАССР им. П.А. Ойунского (1966), член Союза художников СССР с 1964 г.

Афанасий Мунхалов известен как один из самых достойных, сильных и самобытных представителей российской художественной культуры, как смелый новатор якутского искусства XX века, художник, который создал со своими коллегами якутскую графическую школу, как председатель Союза художников Якутии, пост которого занимал многие годы, вывел графику Якутии на международную арену.

Произведениям Афанасия Петровича присущи масштабность мышления, обращение к сложным темам, умение найти для них самые емкие, образные решения. Это большой мастер, создавший множество прекрасных произведений, которые являются гордостью российского искусства.

Афанасий Петрович Мунхалов, основатель высшего образования Республики Саха (Якутия), долгие годы работал деканом и ведущим профессором кафедры живописи и графики Арктического государственного института культуры и искусств. Вдохновляя собственным творчеством, редкостной силой личности, открытостью и благожелательностью. Учитель помогал своим коллегам, ученикам раскрыть свою индивидуальность, реализовать свое творческое видение.

Цель паблик-арта - привлечь внимание к искусству и дать всем желающим возможность реализовать себя.

Концепция паблик-арта, основанная на всесторонней популяризации современного искусства, изначально была утопичной. Большая часть публики так и не научилась толерантно относиться к необычным художественным формам, и, казалось бы, идея «общественного искусства» должна была себя изжить уже после первых неудачных экспериментов, относившихся к 1950-1960м годам. Впрочем, история паблик-арта оказалась долговечной. С одной стороны, эта идея нашла себе воплощение в виде нового типа общественных монументов, создававшихся Генри Муром, Александром Колдером, Жаком Липшицом и другими выдающимися мастерами. С другой - не утратила своей актуальности для разного рода художественных фондов и комитетов, щедро раздающих гранты на поддержку творческих исканий, взаимодействующих с общественными группами [4,5].

Паблик-арт можно считать самым «свободным» из искусств, и оно действительно принадлежит всем и никому, так как не является объектом частной, государственной, церковной или корпоративной собственности [1]. 
Проект межрегионального конкурса «Арт-Мунха. Мой Север-2018» нашел поддержку Фонда будущих поколений Республики Саха (Якутия), благодаря чему идея и была реализована. В создании паблик-арта приняли участие как студенты-художники Арктического государственного института культуры и искусств, так и дети, жители республики.

25 лет назад был создан Целевой фонд будущих поколений Республики Саха (Якутия). В течение четверти века создаёт условия для обеспечения благосостояния и развития будущего республики. Фонд организовывает благоприятные условия для развития способностей одаренных детей и талантливой молодежи Российской Арктики, Сибири и Дальнего Востока в самых разных областях искусства. Это свидетельствует поддержанный фондом Межрегиональный художественный проект «Арт-Мунха-2018. Мой Север», посвященный памяти великого якутского графика Афанасия Мунхалова. Этот проект как никакой другой проект отвечает высоким требованиям, создающим условия для межкультурного диалога, приобщение молодого поколения и широких слоев населения к художественному творчеству.

Концепция проекта заложена в самом сочетании слов «Арт-Мунха», которое созвучно с именем народного художника Афанасия Петровича Мунхалова: «арт»искусство, «мунха»-большая традиционная подледная рыбалка народа саха неводом-мунха. Сочетание этих слов дало емкое креативное представление о назначении мероприятия, призванного вовлечь в сеть-невод творческую энергию молодежи Севера.

Реализация проекта началась с активной подготовки к паблик-арту, при этом под арт-объектом подразумевалась условная заготовка в виде рыбы-карася из березовой фанеры размером 40х70 см., прикрепленная на деревянное основание. Всем материал для работы, кисти и акриловые краски предоставлялись бесплатно. Деревянные караси можно было расписывать как угодно, ограничиваясь только своей фантазией.

Первую публичную презентацию паблик-арта «АртМунха-2018.Мой Север» приурочили к Международному дню защиты детей, об этом событии заранее дали информацию в средствах массовой информации.

1 июня 2018 года на территории сквера, находящегося перед Арктическим государственным институтом культуры и искусств, преподаватели и студенты провели мастер-класс по созданию объектов паблик-арта (общественное искусство в общественном пространстве), в котором приняли участие дети, школьники и их родители. Энергия творчества била ключом: участники настолько увлеклись творческим процессом, что студенты -волонтеры едва успевали приносить новые арт-объекты: количество участников росло с каждой минутой ; расписанные с двух сторон рыбки тут же выставлялись в пространстве сквера. В итоге через два часа под открытым небом в самом центре города Якутска выстроилась многочисленная инсталляция из разноцветных рыбок.

Мастер -класс по паблик -арту дал положительный резонанс, что было отмечено в различных средствах массовой информации. Решено было провести аналогичные мастер-классы в рамках нескольких культурномассовых мероприятий Республики Саха (Якутия): это национальный якутский праздник «Ысыах Туймаады», международная якутская биеннале современного искусства и т.д. Во время проведения Арктической триеннале современного искусства появились инсталляции на фоне заснеженного города. В итоге участниками паблик-арта в совокупности было создано более 1000 артобъектов.

Межрегиональный конкурс детского рисунка «АртМунха-2018. Мой Север» проводился по двум видам изобразительного искусства: «Живопись» и «Графика». Номинации конкурса: «Экология Арктики», «Легенды Арктики», «Мои современники». Участники (учащиеся общеобразовательных учреждений общего и дополнительного образования, учреждений культуры) были разделены на следующие три возрастные категории: дети 6-8 лет, 9-14 лет,15-18 лет. В состав экспертной комиссии вошли Спиридонов Юрий Васильевич- заслуженный художник Российской Федерации, народный художник РС (Я), член союза художников России-председатель экспертной комиссии, Иванова - Унарова Зинаида Ивановна - искусствовед, член союза художников России, заслуженный деятель искусств Российской Федерации, профессор; Тригалева Наталья Вассиановна - искусствовед, ведущий специалист Российской Академии художеств регионального отделения Урала, Сибирь, Дальнего Востока Российской академии художеств в г.Красноярске; Петрова Анна Григорьевна - искусствовед, член союза художников России, кандидат искусствоведения; Иванова Анна Анатольевна - руководитель молодежного объединения «Арт-Мунха».

В Арт-галерее «Ургэл» г. Якутска при большом стечении художников и заинтересованных лиц прошло открытие выставки по итогам Межрегионального конкурса детского рисунка «Арт-Мунха-2018. Мой Север», посвященного памяти народного художника РСФСР, прославленного графика Афанасия Петровича Мунхалова.

Рассмотрев все заявленные работы художников и отбора, экспертная комиссия подвела итоги по двум видам искусства: живопись и графика, по 3 возрастным категориям (6-18 лет), по номинациям: «Экология Арктики», «Легенды Арктики», «Мои современники». Тепло поздравили участников конкурса, отметили красочность 
и профессионализм работ - ректор АГИКИ Саргылана Семеновна Игнатьева; Ирина Геннадьевна Попова - ведущий специалист Целевого фонда будущих поколений PС (Я); Спиридонов Юрий Васильевич - заслуженный художник Российской Федерации, народный художник РС (Я), член союза художников России, Октябрина Прокопьевна Трофимова - супруга Мунхалова А.П.

География участников обширна - это одаренные дети из регионов Сибири, Дальнего Востока, Таймыра, Красноярского края, Норильска, Сахалинской области, Чукотки, Магаданской области и конечно, особое место заняли ребята из арктических улусов Республики Саха (Якутия). На онлайн-конкурс пришло 482 заявки, из которых организаторы выделили 277 участников. В финал вышло 27 победителей.

Критерии оценивания детских работ были очень разнообразны: полнота раскрытия тематики конкурса, новизна, оригинальность композиционного решения, техника исполнения, цветовая гармония, образно-пластическое решение, использование современных технологий и материалов. При рассмотрении работ участников комиссия отметила искренность в выражении любви к своей малой родине юных художников, великолепное знание мифов, легенд и сказок народов Сибири и Дальнего Востока, сохранение традиций искусства народов, населяющих территорию российской Арктики, разнообразие художественно-пластических решений, высокий уровень региональных школ.

Автор проекта Туйаара Шапошникова: «Ребенок закрытый мир, и нам, взрослым, было бы интересно и полезно заглянуть туда. Да и ребенку хочется время от времени выглянуть в большой мир, рассказать о себе. Получается, рисование - это средство коммуникации, способ заявить о себе, получить обратную связь. По результатам конкурса выпущен каталог. Представляете, мы получили одну большую картину, рассказывающую о том, чем живут дети из разных регионов, что их волнует, что привлекает их внимание».

В современном российском художественном образовании искусство рассматривается как универсальный метод построения образовательной среды. Образование, являясь фундаментом культуры, содействует творческому освоению человеком окружающего динамичного, поликультурного мира и достижению социально-культурного благополучия.

\section{ЛИТЕРАТУРА}

1. Иванова, Н.С., Шапошникова, Т.Е. Художественно-творческая деятельность кафедры живописи и графики АГИКИ.Выставка «Арт-Мунха»/ Н.С. Иванова, T.E. Шапошникова// Аргуновские чтения :материалы междунар.науч.-практ.конф. (WORKSHOP), Якутск,11 апр.2016 г./ [под общ. ред. д-ра социол. наук У.А. Винокуровой; ред. совет: Т.И. Аргунова-Лоу, У.А. Винокурова, П.В. Гоголев и др.].-Якутск: ИЦ АГИКИ,2016.4-50 с. -С.382-385.

2. Иванова-Унарова ,3.И., Петрова ,А.Г., Шапошникова, Т.Е. Творческая и художественно-проектная школы Арктического института : [монография-альбом] / [авт.-сост.: 3.И. Иванова-Унарова, А.Г. Петрова, Т.Е. Шапошникова] ; М-во образования и науки Рос. Федерации, ФГБоУ Во «Аркт. гос. ин-т культуры и искусств, каф. дизайна и декаративно-приклад. искусства народов Арктики, каф. живописи и графики. - Якутск: Алаас, 2018. -182 с.

3. Игнатьева С.С., Пинигина О.Н. Социально-культурный потенциал дополнительного образования детей и молодежи в Республике Саха (Якутия), // Современная наука: актуальные проблемы теории и практики. Серия: «Гуманитарные науки» -2019. -№4. -С.64-68.

4. Котломанов, А.О. Патина и паблик-арт//Новый мир искусства. - 2006. -№5. -С.-56-57.

5. Котломанов, А.О. Паблик-арт: страницы истории. Феномен контр-монумента и кризис мемориальной традиции в современной монументальной скульптуре // Вестник СПбГУ. Сер. 15: Искусствоведение. 2015. Вып. 1. С. 53-70. 